\section{Financial Repression in China}

\author{
Nicholas R. Lardy
}

Nicholas R. Lardy has been a senior fellow at the Peterson Institute since 2003. He was a senior fellow in the Foreign Policy Studies Program at the Brookings Institution from 1995 to 2003. He was the director of the Henry M. Jackson School of International Studies at the University of Washington from 1991 to 1995. From 1997 through the spring of 2000, he was the Frederick Frank Adjunct Professor of International Trade and Finance at the Yale University School of Management. His most recent publications are China's Rise: Challenges and Opportunities (2008) and Debating China's Exchange Rate Policy (2008). Other publications include China: The Balance Sheet-What the World Needs to Know Now about the Emerging Superpower (2006), Prospects for a US-Taiwan Free Trade Agreement (2004), Integrating China into the Global Economy (2002), China's Unfinished Economic Revolution (1998), China in the World Economy (1994), Foreign Trade and Economic Reform in China, 1978-1990 (1992), and Agriculture in China's Modern Economic Development (1983). He is a member of the Council on Foreign Relations and of the editorial boards of the China Quarterly, Journal of Asian Business, China Review, and China Economic Review.

Author's note: I wish to thank Vivek Arora, Pieter Bottelier, William Cline, Andrew Crockett, Morris Goldstein, Arvind Subramanian, Edwin Truman, Philip Turner, and John Williamson for comments on an earlier draft of this policy brief. A conversation with Michael Mussa was the original stimulus to write this brief. I am solely responsible for the opinions expressed and any errors herein.

(c) Peter G. Peterson Institute for International Economics. All rights reserved.

China's banking sector has been largely transformed over the past decade. Several of the largest banks have been restructured, recapitalized, and listed. Governance has improved, notably through the appointment of independent members to boards of directors. A vigorous new regulatory and supervisory agency, the China Banking Regulatory Commission (CBRC), has introduced new accounting standards, a revised risk weighting system for measuring capital, more rigorous loan loss criteria, heightened provisioning requirements, and other significant changes. Foreign banks have entered the market, both through their own branches and subsidiaries and through strategic investments in domestic banks, bringing better banking practices and much needed additional competition.
And by most metrics, financial performance of Chinese banks has improved. Nonperforming loans of major commercial banks fell from 17.9 percent of loans outstanding in 2003 to only 6.7 percent in $2007 . .^{1}$ The share of banking assets accounted for by banks meeting the statutory capital adequacy requirement rose from 0.6 to 79 percent over the same period. By 2007 the return on assets and return on equity for the banking sector as a whole rose to a relatively respectable 0.9 and 16.7 percent, respectively. ${ }^{2}$

In one critical respect, however, the financial system appears to have retrogressed. The central bank, the People's Bank of China (PBC), controls interest rates in a way that has led to significant financial repression as inflation has risen in recent years. ${ }^{3}$ As explained in this policy brief, the distorted interest rate structure poses an obstacle to further reform of the financial system and to sustaining China's rapid economic growth.

\section{MEASURING FINANCIAL REPRESSION}

Financial repression, defined here as the low and now negative real return on deposits, is most clearly evident from the point of view of households. One measure is the expanding differential between the nominal interest rate households receive on savings deposits and the rate of consumer price inflation. In February 2002 the PBC fixed the maximum interest rate banks could pay on demand deposits at 0.72 percent, a rate that remains unchanged. ${ }^{4}$ But inflation, as measured by the consumer price index, ticked up by almost 9 percentage points-from -0.8 percent in 2002 to 4.8 percent in 2007 and then to 8 percent in

\footnotetext{
1. The Agricultural Bank of China, the one large state-owned bank that still has not been restructured, accounts for a very large share of these remaining nonperforming loans.
}

2. China Banking Regulatory Commission, 2007 Annual Report (Beijing, 2008), available at www.cbrc.gov.cn (accessed July 2, 2008).

3. While the PBC announces changes in benchmark lending and deposit rates, the State Council holds the ultimate authority to adjust rates.

4. The central bank did raise the demand deposit rate briefly by 9 basis points to 0.81 percent for five months in 2007, between July 21 and December 20 . 
the first quarter of $2008 . .^{5}$ Thus the real rate of return on demand deposits went from 1.52 to -4.08 percent and then to -7.28 percent. Since February 2002, the PBC has increased the rates banks are allowed to pay on term deposits but by far less than the increase in inflation. For example, the oneyear term deposit rate in the first quarter of 2008 was 4.14 percent, an increase of 2.16 percentage points from the rate

\section{[T] he People's Bank of China controls}

$$
\begin{aligned}
& \text { interest rates in a way that has led } \\
& \text { to significant financial repression as } \\
& \text { inflation has risen in recent years. }
\end{aligned}
$$

in February 2002. But that increase is less than a fourth of the increase in the pace of inflation over the same period and has converted a real return of 2.78 percent in 2002 into a real return of -3.86 percent in the first quarter of 2008. Simultaneously, lending rates have also been repressed, as reflected in the sharp decline in real lending rates over the same period (see below).

One measure of the implicit tax imposed on households by the decline in the real return on savings deposits is to estimate how much higher household interest income would have been in the first quarter of 2008 if households had received the same real rate of interest on their net renminbi-denominated savings deposits as in 2002. ${ }^{6}$ Household deposits at the end of the first quarter of 2008 stood at RMB19.1 trillion while their bank borrowings stood at RMB5.3 trillion, making their net deposits RMB13.8 trillion. ${ }^{7}$ The estimated implicit tax on these deposits is RMB255 billion ( $\$ 36$ billion), the equivalent of 4.1 percent of GDP, in the first quarter of $2008 .^{8}$

5. National Bureau of Statistics of China, Overall Stability in National Economic Circulation in the First Quarter (Beijing, April 16, 2008), www.stats. gov.cn (accessed April 16, 2008).

6. Households and corporates also have foreign-currency deposits in banks and borrow foreign-currency funds. The entire analysis in this policy brief is of domestic currency-denominated deposits and loans but hereafter the phrase "renminbi-denominated" will not be repeated.

7. At the end of March 2008, the US dollar-renminbi exchange rate was 1:7.019. To convert renminbi amounts from 2008Q1 to US dollars, divide the renminbi amount by 7.019 . So, net deposits of RMB13.8 trillion divided by 7.019 equals about $\$ 2$ trillion.

8. Demand deposits accounted for 37 percent of all household deposits at the end of 2008Q1. For simplicity the calculation of the amount of additional interest households would have earned if real interest rates had remained unchanged is based on the assumption that all time deposits were one-year deposits. The term of time deposits is as short as three months and as long as five years. However, time deposits of two, three, and five years account for only 5 to 7 percent of total household savings deposits. Most household time deposits
This implicit tax is more than three times the proceeds from the only tax imposed directly on households-the personal income tax. ${ }^{\text {? }}$

Who benefits from this large implicit tax on households? How is the largesse distributed among corporates, banks, and the government itself?

Corporates might be the major beneficiary of financial repression. The real interest rate on loans has plummeted since 2002, and most loans go to corporates, not to households. In 2002 the PBC pegged the benchmark nominal interest rate on a one-year loan at 5.31 percent and producer goods prices fell by 2.3 percent, making the real rate of interest for a corporate borrower 7.6 percent. By contrast, in the first quarter of 2008 the benchmark nominal interest rate on one-year loans was 7.47 percent, but producer price inflation was 7.95 percent, so the real interest rate was -0.5 percent. In short, corporate borrowers in the first quarter of 2008 faced an interest rate on one-year loans that was 8.1 percentage points less in real terms than in 2002! With corporate loans outstanding of RMB22.2 trillion, the implicit subsidy to corporates would appear to be enormous, far more than the implicit tax on households. However, corporates are also large depositors in the banking system, and they face the same low real deposit rates as households. At the end of 2008Q1, nonfinancial corporate bank deposits stood at RMB19.4 trillion, so corporates were net borrowers of only RMB2.8 trillion. The net benefit in the first quarter of 2008 to corporates from financial repression was RMB55 billion, a little less than 1 percent of GDP and about a fifth of the net implicit tax on households.

If only a fifth of the implicit tax on households goes to corporates, then perhaps banks themselves are the biggest beneficiary of financial repression. During 2007, for example, the $\mathrm{PBC}$ raised benchmark interest rates six times. But the central bank left the benchmark rate on demand deposits unchanged, except for a five-month interlude when it raised the rate by only 9 basis points. At the Industrial and Commercial Bank of China (ICBC), China's largest bank, demand deposits accounted for 53 percent of total deposits in 2007. The large share of demand deposits meant that even though the interest rate the bank had to pay on term deposits rose by as much as 171 basis points in $2007,{ }^{10}$ the bank's average cost of funds rose by only 12 basis points compared with

are six-month or one-year deposits. Taking into account the term structure of interest rates on time deposits and the mix of these deposits, the one-year time deposit is an excellent proxy for all time deposits in this calculation.

9. The personal income tax generated RMB319 billion in 2007, 1.3 percent of GDP.

10. The benchmark rate on five-year term deposits rose from 4.14 to 5.85 percent. 
2006 (rising from 1.65 to 1.77 percent). On the other hand, because the PBC raised benchmark lending rates for loans of all maturities, the average yield on the ICBC's loans went up 69 basis points (from 5.42 to 6.11 percent). The spread on the bank's deposit taking and lending business thus rose to 434 basis points from 377 in 2006. With an average of RMB4 trillion in loans outstanding in 2007, the increase in the spread accounted for 40 percent of the increase in ICBC's net interest income in 2007. ${ }^{11}$

But what the PBC grants to banks in the form of cheap deposits it partially or perhaps even largely rescinds through its massive sterilization operations. To initially maintain a fixed nominal exchange rate vis-à-vis the US dollar and since mid-2005, when its new exchange rate policy was announced, to control the pace of renminbi appreciation, the government (acting through the central bank) has been forced to intervene massively in the foreign currency market. This intervention is partially reflected in the growth of official foreign exchange reserves, which rose by $\$ 1.6$ trillion, from $\$ 212$ billion at the end of 2002 to $\$ 1.8$ trillion at the end of June $2008 .{ }^{12}$ To prevent the massive sales of domestic currency (i.e., purchases of foreign exchange) from leading to outsized increases in the domestic money supply, from 2002 through the end of June 2008 the PBC increased the required reserve ratio of banks 21 times, taking the rate from 6 to 17.5 percent. This compelled banks to place an additional RMB5.2 trillion on deposit at the central bank. ${ }^{13}$ The other key instrument the central bank uses to sterilize increases in the domestic money supply is to sell large quantities of central bank bills to banks. At the end of June 2008 banks held RMB4.2 trillion in central bank bills.

Both types of sterilization impose a tax on banks because the nominal rate of interest banks receive on both reserves and

11. Industrial and Commercial Bank of China, "2007 Annual Results Announcement," China Daily, March 26, 2008, 15-22.

12. Central bank intervention in the foreign exchange market substantially exceeded $\$ 1.6$ trillion because the government redeployed some foreign exchange reserves to support other policy objectives during this period, thus reducing the quantity of reserves below the levels that would have otherwise been reported. Beginning in August 2007 the central bank has also required some banks to meet the increases in required reserves by placing foreign-currency rather than domestic-currency funds at the central bank, thus reducing the needed magnitude of central bank intervention in the interbank foreign exchange market. This requirement does not change the amount of foreign exchange held by the central bank but results in identifying part of it as liabilities to banks rather than official foreign exchange reserves.

13. Renminbi bank deposits at the end of June 2008 were RMB 44 trillion. The calculated increase of RMB5.2 trillion does not take into account that urban and rural credit cooperatives and rural cooperative banks, which account for 0.02 percent of deposits in the banking system, face a reserve requirement that is from 1 to $2 \frac{1}{2}$ percentage points below the general rate. Nor does it take into account that banks with capital adequacy less than the statutory rate face a penalty reserve ratio that is one-half percentage point higher than the general rate. central bank bills is below the nominal interest rate that banks would receive if they loaned these funds to customers rather than handing them over to the central bank. For example, the PBC pays banks 1.89 percent on required reserves, a rate unchanged since it was first fixed in February 2002. That rate is well below the average 8.72 percent interest rate banks earned

\section{Financial repression, defined here as}

\section{the low and now negative real return on deposits, is most clearly evident from the point of view of households.}

in March 2008 on loans of six months up to one year in term. ${ }^{14}$ Similarly, central bank bills earn relatively low interest rates. For example, three-year bills sold at the end of June 2008 yield 4.56 percent, far less than the 7.74 percent benchmark interest rate on a three-year loan. The implicit tax imposed on banks in 2007 through the requirement to hold additional low-yielding reserves and central bank bills is RMB230 billion. ${ }^{15}$

But this implicit tax on banks is increasing in 2008 for two reasons. First, $\mathrm{PBC}$ intervention in the foreign exchange market is increasing, so the magnitude of sterilization the central bank must undertake in order to have any prospect for maintaining price stability has increased. Second, since 2007 , the PBC has relied more on increases in the reserve ratio, and the implicit tax on banks associated with reserves is substantially greater than the implicit tax associated with holding central bank bills. ${ }^{16}$ In the first half of 2008 alone the 3 percentage point increase in the reserve ratio meant banks had to deposit an additional RMB1.3 trillion with the PBC, causing the number of banks falling below the statutory 25 percent liquidity ratio to more than quadruple from 85 to 392 by the end of May. No surprise then that the CBRC has reportedly advised the State Council

14. People's Bank of China Monetary Policy Analysis Small Group, Report on Implementation of Monetary Policy in China in 2008Q1 (Beijing, May 14, 2008, 8). www.pbc.gov.cn (accessed May 14, 2008).

15. Morris Goldstein and Nicholas Lardy, China’s Exchange Rate Policy: An Overview of Some Key Issues, in Debating China's Exchange Rate Policy, ed. Morris Goldstein and Nicholas Lardy (Washington: Peterson Institute for International Economics, 2008), 6-7.

16. This is because over the course of 2007 the interest rate paid on central bank bills rose by 90,126 , and 155 basis points, respectively, on three-month, one-year, and three-year maturities. People's Bank of China Monetary Policy Analysis Small Group, Report on Implementation of Monetary Policy in China in 2007Q4 (Beijing, February 22, 2008, 8), www.pbc.gov.cn (accessed February $22,2008)$. On the other hand, as already noted, the central bank has left the interest rate it pays on required reserves unchanged since February 2002. 
not to approve any further increase in the reserve ratio. ${ }^{17}$

Contrary to the initial supposition, the analysis above indicates that Chinese banks are not large net beneficiaries of

\section{Financial repression reduces the cost to}

\section{the government of sterilized intervention}

\section{to sustain China's undervalued exchange} rate relative to the cost it would face

\section{if interest rates were liberalized.}

financial repression. They gain from access to low-cost deposits but lose from the requirement to place funds into low-yielding reserves and central bank bills. In the first quarter of 2008 banks appear to have "captured" about one-quarter of the net implicit tax imposed on households, an amount slightly larger than the gains to corporates.

These calculations mean that the government must be capturing slightly more than half of the implicit net tax imposed on households by financial repression. But how does the government gain from financial repression? In short, the government gains from the implicit tax it imposes on the banks via the PBC's sterilization operations. The cost to the government, and its agent the central bank, of maintaining an undervalued exchange rate is far less than it would be in a more liberalized interest rate environment. In a more liberalized financial environment, the cost of sterilization would rise more over time, putting greater pressure on the authorities to allow the exchange rate to appreciate so as to reduce the external surplus, thus reducing both the needed amount of intervention in the foreign exchange market and the needed magnitude of sterilization operations.

\section{IMPLICATIONS}

Several implications follow. First, the financial repression that has emerged since roughly 2002 appears to be the consequence of the government's policy of maintaining an undervalued exchange rate. In the early years of this decade China's current account was closer to being in balance-for example, the current account surplus in 2001 and 2002 averaged under 2 percent of GDP; the build up of foreign exchange reserves and sterilization operations were both moderate; and interest rates and the required reserve ratio were not significantly distorted.

17. Ma Junqin, "Dangers in Further Increases in the Required Reserve Ratio," July 18, 2008, http://big5.xinhuanet.com (accessed July 31, 2008).
As noted earlier, real deposit and lending rates were both positive, and China's 6 percent required reserve ratio was not an outlier compared with ratios imposed by most central banks. In the late 1990s and early part of this decade the PBC was liberalizing interest rates by allowing increased fluctuations from its established benchmarks. At the time, the government was continuing a fixed nominal exchange rate vis-à-vis the US dollar, a policy initially adopted in the mid-1990s. As the US dollar appreciated in the second half of the 1990s, the renminbi appreciated significantly on a trade-weighted basis, roughly offsetting domestic productivity growth, thus leading to modest annual current account surpluses.

After February 2002, however, the US dollar began to depreciate steadily, leading to a significant real effective depreciation of the renminbi as well. With a lag of a year or so, China's current account surplus began to expand by about 2 percentage points of GDP per year, reaching an all-time high of 11.3 percent of GDP in 2007. As already noted, maintaining initially a fixed nominal exchange rate and after mid-2005 a relatively fixed exchange rate (the renminbi appreciated only about 15 percent on a trade-weighted basis between mid-2005 and mid-2008) in the face of a rapidly rising external surplus required increasing $\mathrm{PBC}$ intervention in the foreign exchange market and, to prevent runaway inflation, large-scale sterilization operations.

Despite rising inflation, the government was reluctant to raise interest rates for fear of attracting even larger speculative inflows, which would have compounded the challenge of controlling the pace of appreciation and the growth of monetary aggregates. The resulting decline in real interest rates as inflation rose has reduced the cost of maintaining an undervalued exchange rate. And the $\mathrm{PBC}$ raised the required reserve ratio to a level unusually high compared with ratios established by other central banks. The central bank in the fourth quarter of 2004 also suspended its program of interest rate liberalization. In short, it is no accident the emergence of financial repression in China has coincided with the government's policy of maintaining an increasingly undervalued currency.

Second, the simultaneous granting of implicit subsidies to banks and imposing implicit taxes on banks makes it difficult to evaluate bank performance. Are the large increases in profits reported by most banks in 2007, for example, the result of improvements in corporate governance, business procedures, risk management, and staff training? Or are they due to the widening of spreads as a result of $\mathrm{PBC}$ control of benchmark interest rates? If the growth of bank profits in 2008 slows compared with that in prior years, does it reflect deteriorating risk management by banks or higher implicit taxes imposed by the PBC's increased sterilization operations? Moreover, aren't 
arbitrary and unanticipated changes in these implicit subsidies and taxes so large that they undermine the incentive of top bank managers to improve the underlying performance of their institutions? In short, while the central government has long articulated the goal of transforming banks to operate on commercial principles, financial repression is fundamentally inimical to achieving that goal.

Third, and related, financial repression has contributed to the expansion of underground finance (dixia jinrong). According to a study by Professor Li Jianzhun of Capital University of Finance and Economics (an affiliate of the Ministry of

\section{[Financial repression] has led to}

\section{lending rates that are far too low,} resulting in excess demand for bank

\section{loans and increased use of quantitative targets to control credit growth.}

Finance), by the end of June 2008 underground lending stood at RMB10 trillion, equivalent to almost a third of the loans extended through the banking system. ${ }^{18}$ The use of belowmarket lending rates and quantitative controls on bank lending insures that there is a large demand for credit that banks do not meet. This drives would-be bank borrowers, particularly less well connected small and medium-sized enterprises, to borrow in the underground financial market, where they pay lending rates well above the benchmark lending rates set by the PBC. Similarly, negative real deposit rates in the banking system provide a substantial incentive for savers to deposit funds in higher interest-paying accounts outside the formal banking system. The huge size of this entirely unregulated market poses significant risks to China's financial system and tends to undermine the ability of the central bank to use monetary policy as an instrument of macroeconomic management.

Fourth, the increasing implicit tax that the government has imposed on household savings has seriously distorted the structure of demand, in turn raising questions about the sustainability of rapid economic growth. Chinese Premier Wen Jiabao in his press conference immediately following the National People's Congress in March 2007 said that "China's economic growth is unsteady, unbalanced, uncoordinated, and unsustainable." Premier Wen's critique was that growth had come to depend disproportionately on increasing invest-

18. "Irregular Credit Completely Offsets the Retrenchment Gap," China Economic Management Report, July 6, 2008. ment spending and a rising external surplus. Consumption as a share of GDP has fallen sharply, and its contribution to growth is now unusually low, in comparison with both other countries and the earlier reform period in China. As early as 2004 the Chinese Communist Party Central Committee formally called for a rebalancing of the sources of economic growth, specifically for an increase in household consumption as a share of GDP. The Party has failed to achieve this goal. Since 2004, the share of household consumption in GDP has continued to fall, cumulatively by almost 5 percentage points of GDP, to the astoundingly low level of only 35.3 percent of GDP in 2007.

One important reason for the continued decline in the contribution of household consumption to China's economic growth is that household income as a share of GDP is declining. A principal reason for this decline is that household interest income as a share of GDP is falling, even though household savings as a share of GDP have risen. In short, as long as financial repression reduces the growth of household income below the path it would otherwise achieve, it is less likely that the government will reach the goal of rebalancing the sources of economic growth. Thus, as we are seeing in 2008, China's economy is vulnerable to a decline in external demand. The pace of growth in 2008 is likely to decline by about 2 full percentage points compared with 2007, as the prior contribution of rising external demand evaporates as global growth slows and household consumption demand continues to languish, reduced below potential by financial repression. This initial growth slowdown should be welcomed, since China was growing above its long-term potential growth rate in 2007. But if the slowdown in global growth deepens and extends well into 2009, the further decline in external demand could slow China's growth rate further, to a level the

\section{Financial repression is inimical to} the government's long-term goal of developing a commercial banking

$$
\begin{aligned}
& \text { system... and has contributed to the } \\
& \text { expansion of underground finance. }
\end{aligned}
$$

leadership regards as inadequate for sustaining job growth and social stability.

Fifth, financial repression makes it less likely that China will be able to develop a fully and efficiently functioning capital market. Financial repression works largely because household savers have few alternative financial assets to bank 
deposits. Equities are an option, but it is hard not to believe that the extreme price volatility in the Chinese equity market in recent years is at least in part a response to the negative returns available on bank deposits. When the market begins to rise, as it did in the second half of 2006, there is a huge flood of money out of bank deposits into equities, driving

\section{[Financial repression] has depressed} the growth of household income, undermining the government's goal of transitioning to a growth path that

\section{relies less on investment and net exports}

\section{and more on domestic consumption.}

prices to almost unheard of multiples, as had happened by the fall of 2007. Then some exogenous event sets off a correction, causing prices and multiples to collapse. By late July 2008 the Shanghai stock index had declined by more than 50 percent compared with its peak in mid-October 2007.

Real assets, notably property, are another alternative to bank deposits for Chinese households. Part of the rapid run up in property prices in urban China in recent years must be due to the negative returns on bank deposits, which has led many households to buy multiple residential properties, with the attendant financial risk that such speculation entails.

China's bond market, although no longer small, is dominated by government paper (treasury bonds, central bank bills, and subordinated debt of state-owned or state-controlled banks), sold largely to banks and other financial institutions in which the government remains the sole owner or controlling shareholder. Outside of short-term commercial paper, corporate bond issuance is minuscule, accounting for only 7 percent of all bonds issued in 2007. If the government wishes to maintain a significantly undervalued exchange rate, it will have to continue intervening in the foreign exchange market and sterilizing most of the resulting increase in the domestic money supply. Thus it will be less likely to allow the development of a range of bonds and alternative financial assets with pricing determined in the market since the cheap funding of the central bank's sterilization operations requires the ongoing large flow of household savings into the banking system.

\section{CONCLUSION}

Financial repression reduces the cost to the government of sterilized intervention to sustain China's undervalued exchange rate relative to the cost it would face if interest rates were liberalized. But the financial repression that facilitates China's undervalued exchange rate imposes substantial, if partially hidden, costs on China's economy. It has led to lending rates that are far too low, resulting in excess demand for bank loans and increased use of quantitative targets to control credit growth. These have led both to a less efficient allocation of capital through the banking system and to a huge underground financial market, which add substantial risks to China's economy.

Financial repression is also inimical to the government's long-term goal of developing a commercial banking system. It also has depressed the growth of household income, undermining the government's goal of transitioning to a growth path that relies less on investment and net exports and more on domestic consumption. Finally, financial repression is a serious obstacle to the development of a robust capital market.

Explicit recognition of these hidden costs of financial repression should be part of the debate on further reform of China's financial and exchange rate system.

The views expressed in this publication are those of the author. This publication is part of the overall program of the Institute, as endorsed by its Board of Directors, but does not necessarily reflect the views of individual members of the Board or the Advisory Committee. 